\title{
CONGRUENCE BETWEEN REAL AND IDEAL LEADER. WHAT MATTERS MORE IN TODAY'S WORK WORLD: ETHICAL BEHAVIOR OF A LEADER OR PRODUCTIVITY?
}

\author{
Aurelija STELMOKIENE் $\mathbb{C D}^{*}$, Auksė ENDRIULAITIENE் \\ Vytautas Magnus University, Kaunas, Lithuania
}

Received 23 December 2019; accepted 05 February 2020

\begin{abstract}
This paper draws from follower centric perspective and implicit leadership theories to explore factors that predict higher congruence between real and ideal leader in followers' view. It also examines the impact of sociodemographic and organizational characteristics to the prediction of perceived congruence. 267 Lithuanian employees from private and public organizations participated in internet-based survey. Followers filled up a questionnaire about their direct middle supervisors: they rated fit between ideal and real leader, leader's ethical behaviour and productivity of work unit. Results indicate that both ethical behaviour of a leader and productivity are important predictors of employees' perceived congruence between real and ideal leader. However, ethical behaviour has significantly higher standardized beta coefficients in comparison with productivity in public sector organizations. Therefore, the context needs to be considered when making leaders' selection and promotion decisions based on follower preferences. Important insights for leadership research are also discussed in the paper.
\end{abstract}

Keywords: congruence, real leader, ideal leader, ethical behaviour, productivity, perception.

JEL Classification: M12, M54.

\section{Introduction}

Globalization has created a market dynamic that demands higher levels of efforts from employees and requires true expertise in leadership (Dinh et al., 2014). With reference to Nichols and Cottrell (2014, p. 728), organization success in such a competitive and global market is likely to increase when the selection, development and promotion of leaders are based on followers' preferences (considering the traits individuals desire). Therefore, analysis of followers' perceived congruence between real and ideal leader is important for organization development. This analysis is even more crucial for Lithuania where follower-centered leadership perspective is still very rare both in empirical studies and practice (Stelmokiene \& Endriulaitiene, 2015).

Besides, scientists still actively debate on soft factors such as subjective perceptions of leader personality or behavior and hard ones, for example, more objective, organizational characteristics that predict preferred leadership. The relationship between technical and moral excellence of a leader still lacks clear answers (Ciulla, 2005, 2012). Due to the intensive competition in the market and recently quite common ethical scandals in business the question if productive or ethical manager leads organization more successfully has come to assume global importance. It seems that sometimes you as a leader are required to choose to be productive or ethical, and it depends on the situation, context.

Moreover, the lenses in leadership research reversed and the relevance of the social perception perspective increased (Oc \& Bashshur, 2013). Therefore, the current research analyzes followers' perception of the leader. It focuses on the effects of raters' sociodemographic and organizational factors on the soft and hard characteristics that employees desire in their leaders. Contextual aspects (for example, type of organization, size of a team, etc.) are considered studying not only ethical leadership (Eisenbeis \& Giessner, 2012), but leader productivity as well. However, the question if the context matters when predicting perceived congruence between real and ideal leader is still unanswered.

Therefore, the purpose of this study is twofold. First of all, we aim to contribute to the leadership literature by suggesting a prediction model of congruence between

*Corresponding author. E-mail: aurelija.stelmokiene@vdu.lt 
real and ideal leader in followers' view. The model combines both soft (represented by ethical behavior in this research) and hard (represented by productivity in this research) characteristics of a leader. Secondly, we seek to add knowledge to the field of leadership context including such contextual variables as sociodemographic raters' characteristics and organizational factors into prediction analysis of perceived leader congruence. The main question of the research is how employees' perceptions about their leader's ethical behavior and their work unit productivity are associated with their experienced congruence between real and ideal leader.

\section{Literature review and hypotheses}

Individuals have beliefs about characteristics a leader needs to possess, and such characteristics compose their leadership schemas (Lord, 1985). In order to understand leadership processes better followers' schemas about leader need to be taken into account (Lord, Brown, \& Freiberg, 1999). Moreover, thorough analysis of followers in the leadership context can explain employees' work results and organizational performance (Uhl-Bien et al., 2014). Employees' preferences for a leader matter in predicting following acts: if I believe in my leader and have favorable perception of him or her I will be willing to follow and to work hard. As a result, a leading act will also be a successful process with desirable results. This link suggested by follower centered perspective is noteworthy for practitioners.

Traditional Implicit leadership theories talk about prototype - typical leader, when analysing employees' perception. However, recent research has showed that "individuals' leader prototype is significantly different from what they desire in a leader" (Nichols \& Cottrell, 2014, p. 718). Moreover, congruency between employees' view of an ideal leader and real leader predicts important organizational outcomes better than congruency between their leader prototype and real leader (Nichols \& Cottrell, 2014). Therefore, it is more valuable for practice to talk about preferences than expectations (ideal versus prototypical leader). Besides, more empirical data about followers' perceived congruence between real and ideal leader would be a significant input into leadership theory: development of follower centred perspective. Preferences for soft and hard characteristics of a leader when evaluating this congruence will be presented more thoroughly in the next section.

\subsection{Do soft (ethical behaviour) or hard (productivity) criteria predict perceived congruence between real and ideal leader better?}

Some qualitative research confirms that employees hope a leader will give clear directions, identify expected results and at the same time will be caring and trustworthy (Stelmokiene \& Endriulaitiene, 2015). In followers' view a leader needs to be responsible for achieving unit goals (be productive) and creating a trusting environment (lead ethically). But what ratio between leader's ethical behavior and productivity is the best in followers' view?

According to Ciulla (1995, p. 17) "ethics lies at the heart of leadership studies". Current research confirms that employees desire leaders whom they can trust, and leader trustworthiness is related with followers' extra efforts (Nichols \& Cottrell, 2014). Employees are willing to work without fear to be cheated. Although a moral character is a necessary part of the leadership definition (Levine \& Boaks, 2014), it should be considered that each of us have different subjective image of a moral (ethical) leader. The widely shared definition of ethical leadership emphasizes "the demonstration of normatively appropriate conduct... and the promotion of such conduct to followers" (Brown, Trevino, \& Harrison, 2005, p. 120). Ethical behavior is identified as the main attribution of an ethical leader. However, the question remains if an ethical behavior is enough for an ideal leader.

Moral challenges of power and successful functioning of an organization in a competitive environment are daily tasks for a leader (Ciulla, 2005). Sometimes a leader needs to make immoral decisions in order to accomplish goals. Additionally, there are still common practices in traditional organizations to judge leaders and followers only by the results not the process. In practice, organizations seek for a leader who knows how to get high results and results are identified as objective criteria of effective leadership (Kaiser, Hogan, \& Craig, 2008). This notion is common among followers as well. However, researchers suggest that process variables are better indicators of leadership effectiveness and they should change dominance of job performance as an outcome variable (Day et al., 2014; Sparrow \& Cooper, 2014). So, the question if ethical behavior or productivity of a leader predicts followers' perceived congruence between real and ideal leader better is still not answered.

Levine and Boaks (2014) argue that employees desire both ethics and power from their leaders. Ciulla (1995) agrees with Aristotle's insight that both moral and technical excellences are required for good leadership. These two parts are necessary for the development of an organization and employees. It is expected that a leader will serve the organizational goals and take care of employees. When looking at the other side of the coin, analysis of productivity and ethics helps to distinct a leader from a manager (Ciulla, 2005). Besides, most often productivity is desired by central office and investors, ethical behavior of a leader - by employees in Western cultures. We hypothesize that both ethical behavior and productivity predict higher congruence between ideal and real leader in followers' view (Hypothesis 1). Our research will propose empirical evidence for the theoretical assumptions about possible predictors for perceived leader congruence from Lithuania, Post-Soviet culture, where ethical leadership research is largely silent (Eisenbeiss, 2012) and employee preferences can be quite different than in Western Europe. Moreover, it 
is desirable that data should be from various organizational contexts. So, survey in private and public organizations will satisfy this demand.

\subsection{Do raters' sociodemographic and organizational characteristics affect prediction of perceived congruence between real and ideal leader?}

Follower centered perspective emphasizes the influence of employees in a leadership context. Attention is paid to individual characteristics of followers that could predict different views of an ideal leadership (Mount \& Scullen, 2001; Oc \& Bashshur, 2013).

Gender, age, work experience and education are the main sociodemographic characteristics that get more attention from researchers than others but are still under the discussion (Duehr \& Bono, 2006). Female employees in comparison with male employees have more positive attitudes towards others and lower requirements for an ideal leader, their standards are more flexible (Correll, 2004; Powell \& Butterfield, 2003). Besides, females are more cautious responders and process data more comprehensively (Meyers-Levy \& Loken, 2015). Older age and longer work experience are related with employees' practical knowledge and education represents the degree of theoretical knowledge. Both practical and theoretical knowledge gives an insight about a difficult and complex leader's role and predicts lower employees' requirements for an ideal leadership (Duehr \& Bono, 2006; Starbuck \& Mezias, 1996). Researchers associate sociodemographic differences with the extent of congruence between ideal and real leader. With reference to literature, in this study we expect that sociodemographic characteristics of employees make difference for the perceived leader congruence. Female, older, with longer work experience and higher education degree employees will report higher congruence between ideal and real leader in comparison with male, younger, with shorter work experience and lower education degree employees ( $\mathrm{Hy}$ pothesis 2).

The impact of context on organizational behavior can't be ignored, as well (Johns, 2006). Moreover, according to Dinh and Lord (2012), situational factors can affect perception of an ideal leadership. For example, competitive contexts require dominance and task orientation, whereas cooperative situations demand interpersonal skills. With reference to these findings, view of an ideal leader could also vary depending on different situations. Organizational differences are associated with the type of preferences, particular predictors of perceived congruence between real and ideal leader. Type of the organization very often represents different situations for a leader: private and public organizations and their leaders experience different inside and outside requirements and therefore have different goals. Private sector is associated with exact economic goals and public sector gets more diverse expectations with stronger social orientation. Besides, public sector gives less discretion in exercising leadership in comparison with private organizations because of the number of rules and less flexible environment
(Hooijberg \& Choi, 2001). Based on the previous study, we propose that different factors will predict perceived leader congruence in private and public sector. Productivity will predict higher congruence between ideal and real leader in private organization (Hypothesis 3a). Ethical behavior will predict higher congruence between ideal and real leader in public organization (Hypothesis 3b).

The field that examines situational factors together with the analysis of employees' sociodemographic characteristics in the context of employees' leadership preferences is still under-studied and needs more empirical evidence. Therefore, this study addresses the current issue. Moreover, analysis of impact of individual and organizational characteristics to the prediction of perceived congruence between real and ideal leader is based not only on the extent of perceived leader congruence, but also on the type (soft and hard characteristics) of predictors. Thus, it gives an additional knowledge.

\section{Research methodology}

\subsection{Sample and data collection}

Cross sectional quantitative empirical research involved 267 followers (73\% females, $27 \%$ males). A convenience sample was recruited from service sector organizations both private (46.4\%) and public (53.6\%) ones in Lithuania. Participants' average age was 36.5 (SD - 9.89). Employees' work experience ranged from 1 until more than 40 years (M - 14.3, SD - 9.57). Majority of them (75 percent) had higher education.

Researchers communicated with human resource managers of service sector organizations and after the agreement to implement the survey in particular organization links to the survey with an explanatory text were send via employees' work e-mail. Participants filled up a self-administered questionnaire about their direct middle supervisors. It consisted of a Single item Graphic Scale (Shamir \& Kark, 2004), a short version of Ethical Leadership Scale (Brown et al., 2005) and a question about their unit productivity. Voluntary participation in the research and confidentiality were guaranteed.

\subsection{Measures and instruments}

Perceived congruence between real and ideal leader was measured with a Single item Graphic scale (Shamir \& Kark, 2004) (Figure 1). The chart was presented to employees with the instruction to choose the one out of the 7 rectangles that most highly represents the extent of congruence between their ideal leader and real direct leader in the organization. There were two circles - one representing ideal and the other real leader, in each rectangle. In each rectangle the circles were overlapping differently (from totally separate, different till totally overlapping, very similar). Bigger overlapping of circles means higher congruence between ideal and real leader.

A short version of Ethical Leadership Scale (Brown et al., 2005) was used to evaluate perceived leader's ethical behavior. Employees were asked to describe how 


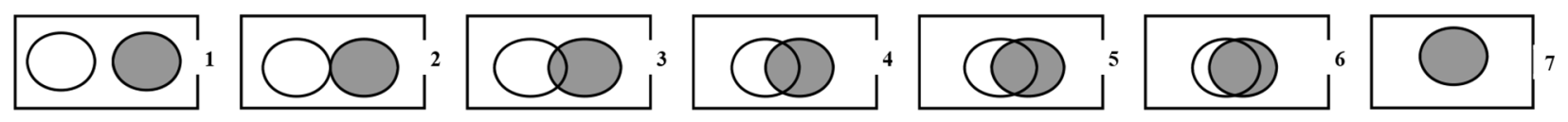

Figure 1. Single item graphic scale

frequently their leader engages in the defined behavior (for example, my leader makes fair and balanced decisions; my leader disciplines employees who violate ethical standards). All six items in the questionnaire were measured on a five-point Likert scale (from 1 - rarely or never, till 5 - very frequently, if not always). Higher score means that leader more often demonstrates ethical behavior. It was a soft (subjective perception of a leader behavior) predictor of perceived congruence between real and ideal leader in the research. Cronbach alpha -0.863 confirmed reliability of the scale.

The request to rate productivity of employees' work unit from 0 percent till 100 percent helped to assess perceived productivity of their direct leader who was responsible for the unit. Higher percent means better results of the unit. It was supposed that productivity of the unit would represent hard (more objective, organizational factor) predictor of perceived congruence between real and ideal leader in the research: this question was in the section of sociodemographic information, not related with questions about the leader.

Additional questions about employees' gender, education level, age and work experience were included in the questionnaire.

\section{Results}

Results of the research are presented in a couple of steps: first, descriptive statistics are introduced and after that the test of hypotheses is explained. Table 1 presents the correlation matrix, mean scores and standard deviations for all the main variables.

Group comparisons, correlation and linear regression analyses were used for further data analysis. In order to test the first hypothesis linear regression analysis was employed. Results of the analysis (Table 2) suggested that both ethical behaviour and productivity were significant predictors of perceived congruence between real and ideal leader. If a real leader is evaluated as ethical and productive, he will be rated as similar to an ideal. However, productivity in comparison with ethical behaviour had

Table 1. Descriptive statistics and correlation matrix for the main variables

\begin{tabular}{|l|c|c|c|c|}
\hline \multicolumn{1}{|c|}{ Variable } & Mean & SD & 1 & 2 \\
\hline $\begin{array}{l}\text { Perceived congruence bet- } \\
\text { ween real and ideal leader }\end{array}$ & 4.45 & 1.551 & & \\
\hline Ethical behaviour & 3.6 & 0.871 & $0.539^{* *}$ & \\
\hline Productivity & 81.48 & 15.96 & $0.344^{* *}$ & $0.332^{* *}$ \\
\hline
\end{tabular}

Note: ${ }^{\star *}$ correlation is significant at the 0.01 level. lower standardized beta coefficients (had lower prediction value). The first hypothesis was confirmed.

Table 2. Leaders' ethical behaviour and productivity as predictors of perceived congruence between real and ideal leader (whole group of participants)

\begin{tabular}{|l|l|c|c|c|}
\hline Model & Predictor & $\begin{array}{c}\text { Std. beta } \\
(\mathrm{p})\end{array}$ & $\begin{array}{c}\mathrm{R} \\
\text { square }\end{array}$ & F (p) [df1; df2] \\
\hline I & $\begin{array}{l}\text { Ethical } \\
\text { behaviour }\end{array}$ & $\begin{array}{c}0.539 \\
(<0.001)\end{array}$ & 0.290 & $\begin{array}{c}108.687(<0.001) \\
{[1 ; 266]}\end{array}$ \\
\hline II & Productivity & $\begin{array}{c}0.344 \\
(<0.001)\end{array}$ & 0.118 & $\begin{array}{c}35.54(<0.001) \\
{[1 ; 265]}\end{array}$ \\
\hline \multirow{2}{*}{$\begin{array}{l}\text { III } \\
\text { integ- } \\
\text { rated }\end{array}$} & $\begin{array}{l}\text { Ethical } \\
\text { behaviour }\end{array}$ & $\begin{array}{c}0.477 \\
(<0.001)\end{array}$ & 0.322 & $\begin{array}{c}62.792(<0.001) \\
{[2 ; 264]}\end{array}$ \\
\cline { 2 - 4 } & Productivity & $\begin{array}{c}0.190 \\
(<0.001)\end{array}$ & & \\
\hline
\end{tabular}

Note: dependent variable - perceived congruence between real and ideal leader.

Secondly, comparison of perceived ideal leadership in groups by gender, education level and type of the organization is introduced (Table 3). Male and female employees perceived congruence between real and ideal leader quite similar. No significant differences of perceived leader congruence were found between groups of employees with different education as well. However, there was a tendency that the congruence between real and ideal leader was lower in private sector. There were no significant correlations between perceived leader congruence and employees' age, work experience (respectively $r=0.093 ; p=0.129$ and $r=0.117 ; p=0.056)$. With reference to results, the second hypothesis should be rejected.

Table 3. Relationships between perceived leader congruence and raters' socio-demographic, organizational characteristics (results of t-test)

\begin{tabular}{|c|c|c|c|c|}
\hline \multirow{2}{*}{\multicolumn{2}{|c|}{$\begin{array}{c}\text { Socio-demographic } \\
\text { and organizational } \\
\text { characteristics }\end{array}$}} & \multirow{3}{*}{$\begin{array}{c}\text { Sample } \\
68\end{array}$} & \multicolumn{2}{|c|}{$\begin{array}{c}\text { Perceived congruence } \\
\text { between real and ideal } \\
\text { leader }\end{array}$} \\
\hline & & & Mean (SD) & $\mathrm{t}(\mathrm{p})$ \\
\hline \multirow{2}{*}{ gender } & male & & $4.62(1.46)$ & \multirow{2}{*}{$\begin{array}{c}0.969 \\
(0.333)\end{array}$} \\
\hline & female & 199 & $4.41(1.58)$ & \\
\hline \multirow{2}{*}{$\begin{array}{l}\text { educa- } \\
\text { tion level }\end{array}$} & $\begin{array}{l}\text { lower than } \\
\text { university } \\
\text { education }\end{array}$ & 67 & $4.3(1.56)$ & \multirow{2}{*}{$\begin{array}{l}-0.966 \\
(0.335)\end{array}$} \\
\hline & $\begin{array}{l}\text { university } \\
\text { education }\end{array}$ & 200 & $4.51(1.55)$ & \\
\hline \multirow{2}{*}{$\begin{array}{l}\text { type of } \\
\text { the orga- } \\
\text { nization }\end{array}$} & public & 143 & $4.6(1.64)$ & \multirow{2}{*}{$\begin{array}{c}1.663 \\
(0.097)\end{array}$} \\
\hline & private & 124 & $4.28(1.43)$ & \\
\hline
\end{tabular}


Group comparisons showed tendencies of differences of perceived leader congruence among private and public sectors. Therefore, additional linear regression analysis (Table 4) was done for two separate groups that were split by the type of the organization.

Table 4. Leaders' ethical behaviour and productivity as predictors of perceived congruence between real and ideal leader (two groups of employees: from private and from public organizations)

\begin{tabular}{|c|c|c|c|c|}
\hline Group & Predictor & Std. beta $(\mathrm{p})$ & $\begin{array}{c}\mathrm{R} \\
\text { square }\end{array}$ & $\begin{array}{c}\mathrm{F}(\mathrm{p}) \\
{[\mathrm{df} 1 ; \mathrm{df} 2}\end{array}$ \\
\hline $\begin{array}{l}\text { I } \\
\text { public } \\
\text { sector }\end{array}$ & $\begin{array}{l}\text { Ethical } \\
\text { behaviour } \\
\text { Productivity }\end{array}$ & $\begin{array}{c}0.570(<0.001) \\
0.188(0.006)\end{array}$ & 0.427 & $\begin{array}{c}53.954 \\
(<0.001) \\
{[2 ; 140]}\end{array}$ \\
\hline $\begin{array}{l}\text { II } \\
\text { private } \\
\text { sector }\end{array}$ & $\begin{array}{l}\text { Ethical } \\
\text { behaviour } \\
\text { Productivity }\end{array}$ & $\begin{array}{c}0.381(<0.001) \\
0.201(0.017)\end{array}$ & 0.213 & $\begin{array}{c}17.646 \\
(<0,001) \\
{[2 ; 121]}\end{array}$ \\
\hline
\end{tabular}

Note: dependent variable - perceived congruence between real and ideal leader.

Leader's ethical behaviour and productivity explained only 21 percent of variance of perceived congruence between real and ideal leader in private sector in comparison with 43 percent of variance in public sector. It could be that employees in private sector have more characteristics (that were not included in the study) in mind when thinking about an ideal leader and evaluating the congruence between ideal and real leader. Besides, ethical behaviour had significantly higher (even 3 times higher) standardized beta coefficients in comparison with productivity only in public sector. Significance of ethical leadership was more emphasized by employees that work in public sector. The third hypothesis was confirmed only partially.

\section{Discussion}

In the context of increasing emphasis on ethics and social responsibility in nowadays organizations, the main purpose of current study was to explore what is more important for employees when they compare their direct manager to ideal leader - ethical behaviour or productivity. Additionally, we tried to answer the question - do raters' sociodemographic and organizational characteristics affect prediction of congruence between real and ideal leader. Based on the results three main contributions to the literature may be drawn.

First of all, the results did not support the hypothesis that individual differences of subordinates (like gender, age, education, and work experience) make a difference how they value the congruence between ideal and real leader. Although Correll (2004), Duehr and Bono (2006), Meyers-Levy and Loken (2015) and Powell and Butterfield (2003) provided data that females and elderly are cautious responders, have more positive attitudes towards others and lower requirements for an ideal leader, our study did not repeat such results. This might be explained in several ways. Our sample was quite homogenous, predominated by highly educated females of quite young age. More heterogeneous samples might produce different results. On the other hand, usually some elaborated selection procedures are employed in service organizations, therefore a higher congruence between employee and leader occurs (Chamorro-Premuzic \& Furnham, 2010; Lang et al., 2012). Consequently, this might lead to fewer preferences for an ideal leader despite socio-demographic differences. Additionally, it might be that individual differences become more important in evaluations where more specified measurements of preferred leadership with gender, trait or role expectancies are used (Hoyt \& Burnette, 2013; Rudman \& Kiliansky, 2010). General measure of congruence between real and ideal leader as it was used in the current study might be not so sensitive to gender, age or education differences. Still this notion should be tested in future investigations. Moreover, there are new trends in the research of sociodemographic characteristics - scientists invite to investigate the influence of employees' generation (X, Y or Z) in leadership context (Anderson et al., 2017).

Second conclusion is consistent to expectations and findings of other researchers. We proposed that both ethical behaviour and productivity predict higher congruence between real and ideal leader in followers' view. Study results revealed that ethical behaviour is more important than productivity for employees; nevertheless, they both are significant predictors of perceived leader congruence. This supports Ciulla (1995) and Levine and Boaks (2014) notions that employees desire both moral and technical excellences from their leaders, and that ethics and productivity do not contradict each other. Classical leadership style theories and new integrative models of leadership behaviour have already stated that good leadership combines concern for people (relations-oriented) and concern for task and results (task oriented) (Behrendt, Matz, \& Goritz, 2017; Eisenbeiss, 2012; Endriulaitiene et al., 2016; Yukl, 2012), therefore new approaches agree that "being regarded as ethical makes a leader effective and being highly effective makes a leader ethical" (Ciulla, 2012, p. 518). The same interactive mechanisms between ethics and productivity are resembled in the recent research. Although ethical leaders are very important in organizational context, expectations of goal attainments (that are frequently associated to productivity in service organizations) are a robust component in people's intuitive notions of ideal leadership (Hoyt \& Burnette, 2013).

Finally, contrary to expectations that productivity will be more important predictor of perceived congruence between real and ideal leader in private organization while ethical behaviour will be more significant in public organization, the results of our study confirmed both factors as important components of leader congruence in followers' view at some extent. Nevertheless, we can conclude that organizational context is important and should be addressed when analysing followers' perspective. Our findings suggest the idea that productivity and ethical behaviour are less significant for leaders in private 
organizations, whereas in public organizations their contribution to followers' perception of congruence between real and ideal leader is much more substantial. This provides some support to Dinh and Lord (2012) and Hooijberg and Choi (2001), who argued that public sector gives less discretion in exercising leadership in comparison with private organizations. Public service organizations usually do not have such strong profit orientation, therefore productivity as the desirable value of leader's behaviour goes to subsidiary place. Whereas organizations in private sector have to deal with different contextual challenges and diverse goals - profit, change, social responsibility, etc. (Endriulaitiene et al., 2016; Yukl, 2012). This situation calls for the diverse competencies and requirements for effective leaders. Also, the results should be understood in the context of leadership levels. Nichols and Cottrell (2014) stated that employees might desire interpersonal traits like ethical behaviour, agreeableness in lower - level leaders who are usually direct supervisors of employees and they desire dominance and productivity in high - level leaders who are usually non- direct supervisors. It might be that in private sector all employees interact more intensively with all levels of leaders and the hierarchy between leaders is confused, whereas in public organizations especially if they are large such interactions are unusual and power distance is bigger (especially in Lithuania). If this is the case, the evaluation of congruence between real and ideal leader is diffuse in private sector and ethical behaviour and productivity becomes of similar value. Still such considerations are not evidence - based and should be tested in future investigations.

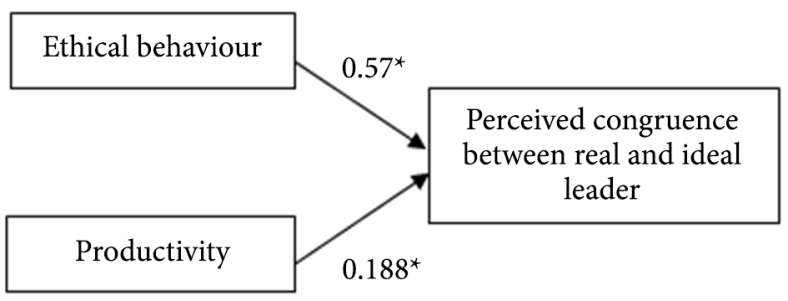

Figure 2a. Prediction model of perceived leader congruence in public sector organization

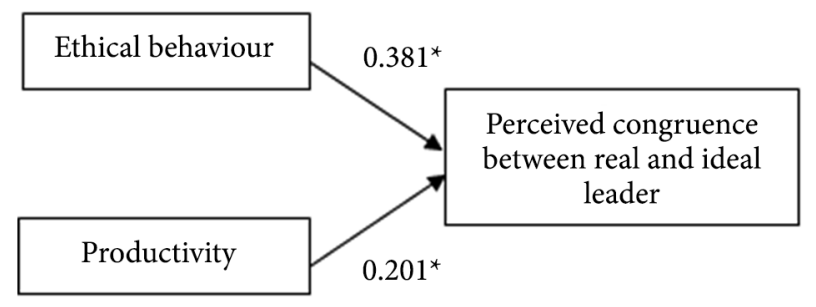

Figure 2b. Prediction model of perceived leader congruence in private sector organization

Nevertheless, the main research question was answered based on empirical data - both ethical behaviour of a leader and productivity were important predictors of employees' perceived congruence between real and ideal leader (Figure $2 \mathrm{a}$ and $2 \mathrm{~b}$ ). Additional data analysis also proposed important insights - stronger significance of the particular factor (in this case, ethical behaviour) was identified only in public sector organizations and it should be taken into account while presenting recommendations for practitioners. However, raters' sociodemographic characteristics didn't show a significant effect in the analysis of perceived leader congruence.

\section{Conclusions}

In summary, our study supports the idea that both ethical behaviour of a leader and productivity are important predictors of employees' perceived congruence between real and ideal leader. However, ethical behaviour has significantly higher standardized beta coefficients in comparison with productivity in public sector organizations. Thus, organizational context is an important variable while predicting congruence between real and ideal leader, and this is an additional knowledge to the field of leadership context. We hope that our study also provides an evidence for the integrated model of factors related to congruence between real and ideal leader: it combines both soft (ethical behaviour) and hard (productivity) characteristics of a leader.

Four limitations in the study need to be taken into account. One limitation is similar to mentioned in Nichols and Cottrell (2014). We did not ask participants to provide answers about what they desire in their leader and measured a congruence between real and ideal leader. We assumed that if employee describes his real leader as ethi$\mathrm{cal}$ and productive and reports high congruence between ideal and real leader, this means these two characteristics are important for perceived ideal leadership. Although the assumption of implicit leadership theories (Littrell, 2013) that this congruence reveals the desires of employee lies behind such measurement, it might not be the case. Employees might not always want ideal leader instead of prototypical (Lord et al., 1999) and we encourage testing these measurement deficiencies in future research. Also, we did not control for participants' individual differences like value preferences that might be an important factor in the context of ethical behaviour. Followers are not homogeneous group and their preferences for ideal leader could depend on various individual characteristics (Bastardoz \& Van Vugt, 2019). Future research should also try to represent both male and female participants more equally. Female employees dominated in our sample, especially in organizations from private sector. Women quite often are more willing to participate in research. Besides, they are really a bigger group in comparison with men in service sector organizations (with reference to data from Lithuanian statistics department). Finally, chosen design for data collecting didn't let us avoid common-method bias. Other data sources (e.g. objective data from reports about productivity) could be employed in future research. 
Despite limitations the results of current study may be useful for selection, development and promotion of leaders and provide practical guidelines how to increase the success in leadership and organization, taking into account employees' perceptions. Follower-centered perspective highlights that employees' perceptions about the leader have bigger power for unit/organization success than objective leader characteristics (traits, behavior, etc.) (Banutu-Gomez, 2004). So, with reference to the findings, first of all, leaders should be ready to use integrative roles combining task orientation and ethical behavior in their daily activities so that followers would experience the effect of them. Employees need to trust that leaders are able to do both tasks: to be productive and behave ethically. Besides, human resource managers should be aware about the importance of the context when making leaders' selection and promotion decisions. Sector (the type of organization) becomes an important variable in the analysis of leadership preferences. Findings propose that ethical behavior of a leader would add credentials to be more powerful and worth for following especially in public sector organizations.

To sum up, while thinking about the development of organizations it can't be forgotten that leadership is in the eyes of followers (Carsten et al., 2019). Their perception really matters. This notion is common in Western cultures and should be brought into scene of Lithuanian organizations.

\section{References}

Anderson, H. J., Baur, J. E., Griffith, J. A., \& Buckley, M. R. (2017). What works for you may not work for (Gen)Me: Limitations of present leadership theories for the new generation. Leadership Quarterly, 28, 245-260.

https://doi.org/10.1016/j.leaqua.2016.08.001

Banutu-Gomez, M. B. (2004). Great leaders teach exemplary followership and serve as servant leaders. Journal of American Academy of Business, 4(1/2), 143-151.

Bastardoz, N., \& Van Vugt, M. (2019). The nature of followership: Evolutionary analysis and review. The Leadership Quarterly, 30(1), 81-95. https://doi.org/10.1016/j.leaqua.2018.09.004

Behrendt, P., Matz, S., \& Goritz, A. S. (2017). An integrative model of leadership behaviour. Leadership Quarterly, 28, 229-244. https://doi.org/10.1016/j.leaqua.2016.08.002

Brown, M. E., Trevino, L. K., \& Harrison, D. A. (2005). Ethical leadership: A social learning perspective for construct development and testing. Organizational Behaviour and Human Decision Processes, 97, 117-134.

https://doi.org/10.1016/j.obhdp.2005.03.002

Carsten, M. K., Bligh, M. C., Kohles, J. C., Wing-Yan Lau, V. (2019). A follower-centric approach to the 2016 US presidential election: Candidate rhetoric and follower attributions of charisma and effectiveness. Leadership, 15(2), 179-204. https://doi.org/10.1177/1742715018817930

Chamorro-Premuzic, T., \& Furnham, A. (2010). The psychology of personnel selection. New York: Cambridge University Press. https://doi.org/10.1017/CBO9780511819308

Ciulla, J. B. (1995). Leadership ethics: Mapping the territory. Business Ethics Quarterly, 5(1), 5-28.

https://doi.org/10.2307/3857269
Ciulla, J. B. (2005). The state of leadership ethics and the work that lies before us. Business Ethics: A European Review, 14(4), 323-335. https://doi.org/10.1111/j.1467-8608.2005.00414.x

Ciulla J. B. (2012) Ethics effectiveness: The nature of good leadership. In: D. V. Day \& Antonakis, J. (Eds.), The nature of leadership (2nd ed.) (pp. 508-540). Los Angeles, CA: Sage.

Correll, S. J. (2004). Constraints into preferences: Gender, status and emerging career aspirations. American Sociological Review, 69(1), 93-113. https://doi.org/10.1177/000312240406900106

Day, D. V., Fleenor, J. W., Atwater, L. E., Sturm, R. E., \& McKee, R. A. (2014). Advances in leader and leadership development: A review of 25years of research and theory. Leadership Quarterly, 25(1), 63-82.

https://doi.org/10.1016/j.leaqua.2013.11.004

Dinh, J. E., \& Lord, R. G. (2012). Implications of dispositional and process views of traits for individual difference research in leadership. Leadership Quarterly, 23(4), 651-669.

https://doi.org/10.1016/j.leaqua.2012.03.003

Dinh, J. E., Lord, R. G., Gardner, W. L., Meuser, J. D., Liden, R. C., \& Hu, J. (2014). Leadership theory and research in the new millennium: Current theoretical trends and changing perspectives. Leadership Quarterly, 25(1), 36-62. https://doi.org/10.1016/j.leaqua.2013.11.005

Duehr, E. E., \& Bono, J. E. (2006). Men, women, and managers: Are stereotypes finally changing? Personnel Psychology, 59, 815-846. https://doi.org/10.1111/j.1744-6570.2006.00055.x

Eisenbeiss, S. A. (2012). Re-thinking ethical leadership: an interdisciplinary integrative approach. Leadership Quarterly, 23, 791-808. https://doi.org/10.1016/j.leaqua.2012.03.001

Eisenbeiss, S. A., \& Giessner, S. R. (2012). The emergence and maintenance of ethical leadership in organizations. A question of embeddedness? Journal of Personnel Psychology, 11(1), 7-19. https://doi.org/10.1027/1866-5888/a000055

Endriulaitiene, A., Stelmokiene, A., Minelgaite-Snaebjornsson, I., \& Littrell, F. R. (2016). Ideal leader in the perception of employees from Lithuanian health care. Management of Organizations: Systematic Research, 75, 57-69. https://doi.org/10.7220/MOSR.2335.8750.2016.75.4

Hooijberg, R., \& Choi, J. (2001). The impact of organizational characteristics on leadership effectiveness models: an examination of leadership in a private and a public sector organization. Administration and Society, 33(4), 403-431. https://doi.org/10.1177/0095399701334002

Hoyt, C. L., \& Burnette, J. L. (2013). Gender bias in leader evaluations: merging Implicit theories and Role congruity perspectives. Personality and Social Psychology Bulletin, 39(10), 1306-1319. https://doi.org/10.1177/0146167213493643

Hoyt, C. L., Price, T. L., \& Poatsy, L. (2013). The social role theory of unethical leadership. Leadership Quarterly, 24, 712-723. https://doi.org/10.1016/j.leaqua.2013.07.001

Johns, G. (2006). The essential impact of context on organizational behavior. Academy of Management Review, 31(2), 386408. https://doi.org/10.5465/amr.2006.20208687

Kaiser, R. B., Hogan, R., \& Craig, S. B. (2008). Leadership and the fate of organizations. American Psychologist, 63(2), 96110. https://doi.org/10.1037/0003-066X.63.2.96

Lang, J. W., Zettler, I., Ewen, C., \& Hülsheger, U. R. (2012). Implicit motives, explicit traits, and task and contextual performance at work. Journal of Applied Psychology, 97(6), 12011217. https://doi.org/10.1037/a0029556

Levine, M. P., \& Boaks, J. (2014). What does ethics have to do with leadership? Journal of Business Ethics, 124, 225-242. https://doi.org/10.1007/s10551-013-1807-y 
Littrell, F. R. (2013). Explicit leader behaviour: A review of literature, theory development, and research project results. Journal of Management Development, 32(6), 567-605. https://doi.org/10.1108/JMD-04-2013-0053

Lord, R. G., Brown, D. J., \& Freiberg, S. J. (1999). Understanding the dynamics of leadership: the role of follower self-concepts in the leader/follower relationship. Organizational Behavior and Human Decision Processes, 78(3), 167-203. https://doi.org/10.1006/obhd.1999.2832

Lord, R. G. (1985). An information processing approach to social perceptions, leadership and behavioral measurement in organizations. Research in Organizational Behavior, 7, 87-128.

Meyers-Levy, J., \& Loken, B. (2015). Revisiting gender differences: What we know and what lies ahead? Journal of Consumer Psychology, 25(1), 129-149.

https://doi.org/10.1016/j.jcps.2014.06.003

Mount, M. K., \& Scullen, S. E. (2001). Multisource feedback ratings: What do they really measure? In: M. London (Ed.), How people evaluate others in organizations (pp. 155-180). US: Lawrence Erlbaum Associates.

Nichols, A. L., \& Cottrell, C. A. (2014). What do people desire in their leaders? The role of leadership level on trait desirability. Leadership Quarterly, 25(7), 11-729. https://doi.org/10.1016/j.leaqua.2014.04.001

Oc, B., \& Bashshur, M. R. (2013). Followership, leadership and social influence. Leadership Quarterly, 4(6), 919-934. https://doi.org/10.1016/j.leaqua.2013.10.006

Powell, G. N., \& Butterfield, D. A. (2003). Gender, gender identity, and aspirations to top management. Women in Management Review, 18(1/2), 88-96.

https://doi.org/10.1108/09649420310462361
Rudman, L. A., \& Kiliansky, S. E. (2010). Implicit and explicit attitudes toward female authority. Personality and Social Psychology Bulletin, 26(11), 1315-1328.

https://doi.org/10.1177/0146167200263001

Shamir, B., \& Kark, R. (2004). A single-item graphic scale for the measurement of organizational identification. Journal of Occupational and Organizational Psychology, 77, 115-123. https://doi.org/10.1348/096317904322915946

Sparrow, P., \& Cooper, C. (2014). Organizational effectiveness, people and performance: new challenges, new research agendas. Journal of Organizational Effectiveness: People and Performance, 1(1), 2-13. https://doi.org/10.1108/JOEPP-01-2014-0004

Starbuck, W. H., \& Mezias, J. M. (1996). Opening Pandora's box: studying the accuracy of managers' perceptions. Journal of Organizational Behavior, 17, 99-117. https://doi.org/10.1002/ (SICI)1099-1379(199603)17:2<99::AID-JOB743>3.0.CO;2-2

Stelmokiene, A., \& Endriulaitiene, A. (2015). An assessment of leadership effectiveness: psychological aspects (monograph). Lithuania: Versus Aureus, Vytautas Magnus University.

Uhl-Bien, M., Riggio, R. E., Lowe, K. B., \& Carsten, M. K. (2014). Followership theory: A review and research agenda. Leadership Quarterly, 25, 83-104. https://doi.org/10.1016/j.leaqua.2013.11.007

Yukl, G. (2012). Effective leadership behavior: What we know and what questions need more attention. Academy of Management Perspectives, (November), 66-85. https://doi.org/10.5465/amp.2012.0088 